\title{
Rozdroża prakseologii w drugiej połowie XX wieku: Tadeusz Kotarbiński i Pierre Bourdieu ${ }^{1}$
}

\author{
JERZY KOLARZOWSKI
}

Uniwersytet Przyrodniczo-Humanistyczny w Siedlcach, ul. Żytnia 17/19, 08-110 Siedlce ORCID: 0000-0001-9074-5927,E-mail: jerzy.kolarzowski@uph.edu.pl

STRESZCZENIE: Pierre Bourdieu i Tadeusz Kotarbiński byli materialistami. Niemniej to francuski badacz społeczny i - w następnej kolejności - myśliciel był materialistą permanentnie epistemologicznym (kwestionował i po wielokroć rekonstruował także własne projekty). Ludzkie zachowania badał w trybie nieufności, bez zaufania do trwałości ustaleń, kwestionując, na ile mogło to przynieść sens, znaczenie otrzymywanych wyników. Natomiast Tadeusz Kotarbiński, charakteryzujący się postawą ateisty naukowego, traktował materializm historyczno-dialektyczny w kontekście teorii bytu społecznego, poszukując supremacji prawdy oraz świata trwałej pewności. Owo zestawienie pozwala przedstawić metodologiczne dylematy prakseologii. Dla Kotarbińskiego prakseologia jest samoistną nauką normatywną, dla Bourdieu zaś ujawnia się spod presji aksjologii - instynktu posiadania, stając się częścią socjologicznej analizy działań (w tym działań komunikacyjnych).

SŁOWA KLUCZOWE: prakseologia, socjologiczna analiza ludzkiego działania, Kotarbiński, Bourdieu

Celem artykułu jest analiza prakseologii w rozumieniu Tadeusza Kotarbińskiego, czołowego polskiego reisty, odznaczonego m.in. Francuską Legią Honorową oraz prakseologia rozwijana przez słynnego socjologa Pierre'a Bourdieu. Działalność Kotarbińskiego rozwinęła się w gorsecie ideologii realnego socjalizmu, z kolei Bourdieu w okresie likwidacji francuskiego imperium kolonialnego i przewrotu antylewicowego elit intelektualnych Francji, a więc w cza-

1 Artykuł w wersji elektronicznej został opublikowany w „Prakseologii i Zarządzaniu” nr 2/2015 na stronie Towarzystwa Naukowego Prakseologii. 
sie procesów schyłku XX-lecia. Cechami wspólnymi dla normatywnej prakseologii Tadeusza Kotarbińskiego i dominium potestas koncepcji socjologiczno-prakseologicznych Pierre'a Bourdieu są uwzględnianie presji czasu oraz otwartość na różne aspekty kontekstu społecznego. Należy jednak pamiętać, że francuski badacz umieszcza prakseologię na obrzeżu filozofii i otacza wieloma wymiarami kontekstów społecznych, ujmowanych żywiołowo. Porównanie myśli Kotarbińskiego i Bourdieu może skutkować ukazaniem ogromnej ilości zagrożeń dla bytu społecznego oraz bezradności refleksji humanistycznej, próbującej chociażby te zagrożenia zdiagnozować.

\section{TADEUSZ KOTARBIŃSKI - PROPAGATOR PRAKSEOLOGII NORMATYWNEJ}

W 1945 roku, po zakończeniu II wojny światowej, Tadeusz Kotarbiński miał 49 lat. W jego dorobku kilkadziesiąt studiów było poświęconych historii filozofii odczytywanej jako program wyłącznie intelektualny. Był zdecydowanym materialistą, głosił marksizm konkretny ${ }^{2}$ i ateistyczny. Przedwojenne prace Kotarbińskiego nad Arystotelesem, Franciszkiem Baconem, Karolem Marksem i Franzem Brentano doprowadziły go do szczególnego rodzaju epistemologii - reizmu. To teoria ontologiczna sprzeciwiająca się istnieniu jakichkolwiek przedmiotów ogólnych w myśl zasady, że istnieją tylko rzeczy. Program intelektualny Kotarbińskiego zakładał uwolnienie filozofii od sporów terminologicznych związanych z nazwami ogólnymi, które określił mianem „terminów pobocznych”, „pseudo-nazw”, a także „słów pozornych”, czyli onomatoid.Polski badacz w swojej drodze filozoficznej zamierzał zatem rozstrzygać dwie płaszczyzny problemów - kwestie teorii poznania i klasyfikacji nauk. W ramach klasyfikacji nauk prakseologia, zgłoszona pod koniec XIX wieku przez Alfreda Espinasa (ucznia pozytywisty Augusta Comte'a) jako postulat samoistnej dyscypliny naukowej, na pewien czas zakończyła spory o taksonomię metodologii naukowych. Ponadto, będąc nauką szalenie redukcjonistyczną, została „pogodzona” z marksizmem, do którego Kotarbiński miał życzliwy stosunek. Podobne nastawienie do marksizmu przejawiał logik Stanisław Leśniewski i część środowiska szkoły lwowsko-warszawskiej. W środowiskach intelektualnych drugiej RP uważano, że postęp cywilizacyjno-naukowy jest wartością nieodzowną, podobnie jak zrealizowanie postulatów modernizacji społecznej. Nie wiązano także marksizmu z eksperymentem bolszewickim, który w swych początkach (lata dwudzieste XX wieku) przybierał niejednoznaczne oblicze ideowe ${ }^{3}$.

2 Marksizm konkretny oznacza w tym przypadku taką recepcję materializmu, dla której w każdym przypadku ostateczną instancją rozstrzygającą wszelkie wątpliwości jest praktyka zarówno naukowa, jak i płynąca $\mathrm{z}$ doświadczenia dnia codziennego.

3 Upaństwowioną gospodarkę promowali od początku XX wieku również Niemcy, a w ZSRR w latach dwudziestych otworzono więcej bożnic (żydowskich domów modlitewnych) niż w całym poprzednim okresie istnienia państwa rosyjskiego. Niektórzy bolszewicy, jak np. gen. Swierdłowsk, mieli pochówki zgodne z żydowskim rytuałem pogrzebowym. W Rosji radzieckiej w pierwszej dekadzie po rewolucji i wojnie domowej ścierały się ze sobą marksizm, anarchizm (Sawinkow) i nacjonalizm (Por. Sołżenicyn 2014, Zubow 2015). 
W reizmie Kotarbińskiego każda rzecz jest jednocześnie ciałem (pansomatyzm) i obiektem badań. Jego program naukowy zbliżał się do fizykalizmu. Fizykalistyczny materializm mógł się przeciwstawić zarówno psychologizmowi (manierze naukowej trapiącej humanistykę przełomu XIX i XX wieku), jak i stać się czymś równie atrakcyjnym w swej odmienności co fenomenologia. Jednak zarówno w przyrodzie jak i w życiu społecznym wszelkie ciała są w ruchu oraz we wzajemnej relacji. Dla objaśniania dążeń i relacji między ludźmi Tadeusz Kotarbiński proponował prakseologię - samoistną naukę o działaniach człowieka oraz o sposobach ich doskonalenia.

Co do prakseologii, to głównym jej zadaniem jest opracowywanie zaleceń i przestróg dotyczących sprawnego, czyli racjonalnego, działania w ogóle, a więc ważnych we wszystkich dziedzinach działania ludzkiego, zarówno w gospodarstwie, jak w obronie militarnej, lecznictwie, sądownictwie, szkolnictwie, etc. (Kotarbiński 1986: 259).

Prakseologia jest zatem fragmentem rozważań filozoficznych, który występuje w różnych systemach - szczególnie racjonalistycznych, poczynając od Arystotelesa - i oznacza zarówno opis, jak i ocenę działań człowieka:

[...] jest obecne we wszelkim działaniu, co bywa ważne przy jego charakterystyce, mianowicie działamy zawsze w jakimś otoczeniu. Składają się na nie środowisko, czyli ogół rzeczy otaczających, i sytuacja, czyli ogół stanów tych rzeczy lub ich zmian w czasie odbywania się działania. A przez czas odbywania się działania, rozumie się tutaj okres od początku impulsu dowolnego aż do końca zmiany będącej skutkiem działania (Kotarbiński 1974: 33).

Działania mogą być skuteczne, nieskuteczne lub przeciw-skuteczne. Redukując pewne problemy do opisu i oceny działań, pomija się rozważania nad świadomością, wolą, intencją czy emocjami na każdym etapie aktywności ludzkiej. Jest więc prakseologia - jeśli tak można powiedzieć - filozoficzną nadbudową nad ergonomią, nauką o zewnętrznym, fizykalnym ruchu organizmu człowieka za cenę znaczących redukcji, dotyczących neuronów i psychiki, które to aktywności nie są brane w niej pod uwagę, co z kolei oznacza pominięcie bardzo wielu problemów. Polemika z tak rozumianym reizmem i jego konsekwencjami zrodziła się wśród pozytywistycznie zorientowanych logików.

Kazimierz Ajdukiewicz zarzucał Kotarbińskiemu, że materialistyczny reizm jest logiczną tautologią, bowiem jeżeli istnieją tylko rzeczy, to każdy przedmiot jest rzeczą i rzeczy nie różnią się niczym od siebie $[\mathrm{a}=\mathrm{r} ; \mathrm{b}=\mathrm{r} ; \mathrm{a}=\mathrm{b}]$. W ramach prakseologii można zatem mówić o stanach oraz cechach działań człowieka i tylko człowieka (nie sił przyrody, zwierząt, czy jakiegokolwiek innego „Kosmicznego Sprawcy”). Fundamentem takiego systemu był konsekwentny ateizm (Kolarzowski 2006: 27-34), a jego dopełnieniem etyka niezależna.

Dla Tadeusza Kotarbińskiego prakseologia miała ponadto dodatkowe walory. Nie tylko opisywała stany i cechy ludzkich działań, ale ponadto sprzeciwiała się marksistowskiemu praktycyzmu (XI teza o Feuerbachu Karola Marksa) i zapowiadała docelowe zniesienie filozofii jako 
nauki. Tak rozumianą prakseologię można było rozdzielić zarówno od uprawianych na zachodzie teorii organizacji jak i od etyki. Wtórność etyki wobec prakseologii wynikała z wcześniej powziętych założeń fizykalnego materializmu i z dwuznaczności koncepcji narzędzia. Autor Traktatu o dobrej robocie pisał:

[...] znawstwo działań skutecznych, wydajnych i oszczędnych jako takie ma charakter czysto instrumentalny. Podobnie jak nóż, może być użyte do różnych celów, zarówno dobrych, jak złych. Czy z tego wynika, że mamy zaniechać wytwarzania noży i posługiwania się nimi? (Kotarbiński 1974: 67).

Prakseologia Tadeusza Kotarbińskiego okazała się dyscypliną normatywną. Jest to normatywność intencjonalna i obejmująca intencje jako impulsy aktywności człowieka. Krok od normatywności intencjonalnej do społeczno-politycznej jest zaiste minimalny. Aktywność człowieka należało poddać wszelkiego rodzaju prawom, instrukcjom i regulacjom. Jednostka ludzka zgodnie z jej postulatami miała zostać sprowadzona do roli samodoskonalącego się urządzenia o tyle podmiotowego, o ile potrafiłaby doskonalić swą własną skuteczność wytwórczą, badawczą i naukową. Problematyka sprawstwa zaczęła więc gubić to wszystko, co można określić jako Conditio Humana, a co było składową hellenistycznego obrazu świata i człowieka.

Rzeczą charakterystyczną i godną osobnych badań jest wiara ogromnej rzeszy marksistów i marksistowskich funkcjonariuszy w prawo, jego siłę i moc - w jego pozytywistycznym znaczeniu. Tendencje jurydyzacyjne charakteryzują wszelkie słabe państwa o trudnej do utrzymania tożsamości wielopokoleniowej, np. społeczeństwo niemieckie.

Prakseologia natomiast źle znosi nadmiar prawa w każdych warunkach czy realiach ustrojowych. Nie do utrzymania okazała się jej jakakolwiek wymiarowość - nawet ta pojedyncza, rozpięta między produkcją a konsumpcją w Stanach Zjednoczonych, o której jako o zagrożeniu pisał w swoim słynnym dziele One Dimentional Man neomarksista Herbert Marcuse (1991).

Po raz kolejny należy podkreślić, że w roku zakończenia II wojny światowej Tadeusz Kotarbiński miał 49 lat. Nie uwzględnił w swoim całym dorobku zagadnienia zróżnicowania wartości pracy (inna wartość pracy fizycznej a inna intelektualnej) (Znaniecki 2013), który to problem stał się zmorą i w dużym stopniu przyczyną klęski całej formacji realnego socjalizmu. Podobnie do usług, które nie mogą zapewnić bogactwa klasy średniej we współczesnym kapitalizmie, praca fizyczna, którą w państwach bloku wschodniego zrównano z pracą intelektualną, nie mogła stworzyć podstaw do wygranej w rywalizacji z Zachodem. Nauka i technika w sprzyjających warunkach mogą być źródłem istotnych dochodów i służyć zwielokrotnionej akumulacji kapitału. Efektywne zarządzanie w skali globalnej powinno zatem uwzględniać wielość aktywności oraz zróżnicowanie dróg pozyskiwania dochodów. Zdarza się, że mijają epoki, w których trudno jest zauważyć różnorodność, szczególnie gdy ta blokowana jest doktrynerskimi założeniami.

W cywilizacji Zachodu, charakteryzującej się powszechną konkurencją, także w zakresie 
reprodukowania przekonań społecznych - to Bourdieu odniósł wiekopomny sukces, jako francuski badacz społeczny i w następnej kolejności myśliciel, który był także epistemologicznym materialistą, kwestionującym i po wielekroć rekonstruującym także własne projekty. Kotarbiński, zwracający się do materializmu historyczno-dialektycznego jako do teorii bytu społecznego, reprezentujący postawę ateisty naukowego, a także będący krzewicielem realnego socjalizmu, pozostał „więźniem własnej wiary”, głoszącym jak wielu innych, słuszność obranych pospołu ideologicznych założeń (Konarzewski 2006: 27-34).

\section{PIERRE’A BOURDIEU PRAKSEOLOGIA WEWNĄTRZ SOCJOLOGII}

Pierre Bourdieu, poprzez konsekwentne włączanie prakseologii do nauk społecznych, uniknął bycia pochłoniętym przez „demona teorii” i skierował nauki społeczne w stronę teorii działań. Wykreowaną przez Bourdieu prakseologię społeczną można utożsamić z permanentną socjoanalizą i uznać za dziedzinę korzystającą w całej rozciągłości z pozytywizmu naukowego, ale bez miejsca na utopię, wiarę czy nawet nieweryfikowalne projekcje. W przeszłości różnorodne komponenty utopii i nieweryfikowalnych idei stanowiły ważne spoiwo czy nawet myślowy horyzont koncepcji zaliczanych do socjologii wiedzy.

Badania jednostkowych aktywności oraz grupowych praktyk znalazło swój wyraz zarówno w tytułach prac francuskiego socjologa, np. Rozum praktyczny. O teorii działania, Zmyst praktyczny, jak i w używaniu pojęć ogniskujących refleksję społeczną na aktach pojedynczych ludzi. Stworzył koncepcję jednostki uniwersalnej, dążącej do różnego rodzaju znaczenia w społeczeństwie. Owo znaczenie można uzyskać poprzez stan posiadania, obraną rolę społeczno-zawodową, otrzymane honory i wpływy wywierane na otoczenie. Trzeba nie tylko być, ale także mieć, np. możliwości i tworzyć rzeczywistość społeczno-ekonomiczną wokół siebie.

Pierre Bourdieu uważał, iż żyjąc w społeczeństwie kapitalistycznym, nie sposób uwolnić się od przejawów uczucia admiracji dla różnych postaci kapitału ${ }^{4}$. Tłumaczył w ten sposób niezwykły wpływ i atrakcyjność ekonomii, przyczyniającą się do nieoczywistego rozwoju pojęcia „kapitału”, które posiadając pewne wspólne elementy z łatwością, przekracza bariery różnych dziedzin wiedzy, determinując oraz zakreślając ich pola badawcze (np. matematyki i historii). Termin ten wraz z przydawkami zdaniowymi rozpoczął ogólnohumanistyczną karierę. Obok kapitału ekonomicznego możemy spotkać się z określeniem „kapitał polityczny” (przekładający się na głosy wyborców), „kapitał społeczny”, „,kapitał kulturowy”, czy schodząc do mikro-relacji kształtujących etosy pracowników - „kapitał zaufania”. Istotnymi pojęciami, które odbierają kapitałowi jego ciężar, okazały się „kapitał symboliczny” i „przemoc symboliczna”.

4 Można jedynie owo uczucie skrywać, kontrolować z pomocą wolnej woli, a za sprawą intelektu dialektycznie odwracać emocjonalną tendencję, pozostając $\mathrm{w}$ wewnętrznym rozdarciu. Np. w trakcie czynności dnia codziennego: robienia zakupów, konstruowania budżetu rodziny, a szczególnie w trakcie oglądania telewizji. Tej ostatniej Bourdieu przypisywał szczególnie negatywną rolę, wskazując, że każdego z widzów stawia w roli jednostki pozbawionej społecznej auto-aktualizacji. 
Jego zdaniem różne rodzaje kapitału mają możliwość przechodzenia od jednej postaci do drugiej (Bourdieu 1982).

Bourdieu uważał, iż każdy badacz społeczny powinien wyznaczyć sobie określone zadanie i obszar jego analizy. Jest to działanie aprioryczne i naznaczone ryzykiem. Pole badawcze będzie wyznaczone prawidłowo o tyle, o ile odkryje się w nim to, co ukryte, nieoczywiste, niepoddające się jednoczynnikowemu wyjaśnieniu. Stąd też często francuski badacz określał swoją aktywność pisarską jako socjoanalizę w nawiązaniu do psychoanalizy Zygmunta Freuda, który to proces miał uzdrawiać przez uświadomienie i wypowiedzenie kwestii tkwiących - w pokładach pamięci, świadomości czy podświadomości. To nader istotna różnica, gdyż przez ten jeden wytrych słowny - socjoanalizę - post-marksista Pierre Bourdieu włączał się w nurt europejskiej filozofii drążącej świat ludzi, poczynając od jaskini Platona (wraz z platońskim pojęciem anamnezy - przypominania sobie wiedzy ukrytej od zarania świata). Zatem socjoanaliza, jak i psychoanaliza, to XX-wieczne nowoczesne postacie platońskiej teorii poznania.

Pierre Bourdieu nie napisał książki przedstawiającej ogólną teorię pola w naukach społecznych ${ }^{5}$. Jednak to niezwykle metaforyczne określenie ${ }^{6}$ (franc. le champ) da się wyjaśnić na podstawie poszczególnych prac badacza. Oznacza ono wycinek struktury społecznej, który charakteryzuje się tym, że skupia jednostki i grupy skoncentrowane na podobnych dążeniach i rywalizujące o pozycję w jego obrębie. Pole aktywności społecznej organizuje się wokół obowiązujących celów, założeń i kryteriów uznawanych za szczególnie ważne. Cele te nazywa niekiedy Bourdieu ,stawką w grze”, jaka toczy się w polu społecznym. Pole społeczne przenika wiele procesów, ale dla socjologa najbardziej rozpoznawalne są te, które toczą się świadomie, a w których to potencjał jednostek uruchamiany jest z duża dozą indywidualnej inicjatywy. Dla podejmujących grę założeniem o priorytetowym znaczeniu, obowiązującym w konkretnym polu, jest wyobrażona stawka nagród, korzyści, uznania, wszelkiego typu satysfakcji, którą kształtujemy przede wszystkim w naszej wyobraźni:

Uwidacznia się tu praktyczna antynomia, jaką musi pokonać nauka, kiedy za cenę zerwania z wszelkimi rodzajami operacjonalizmu, który milcząco akceptuje podstawowe założenia logiki praktycznej nie mogąc ich zobiektywizować, chce w sobie i dla siebie zrozumieć, ale nie po to, by ją zmieniać czy reformować, logikę praktyki, która rozumie tylko po to, by działać (Bourdieu 2008: 123).

Naukowcy pracują głównie umysłami i wyobraźnią (w życiu społecznym popadając często w szczególną antynomię), w przeciwieństwie do całej reszty społeczeństwa, która najpierw dąży do praktyczności, kierując się zyskiem i dążeniami do minimalizowania wysiłku.

Wyobrażeniowy aprioryzm w socjologii czy prakseologii nie jest nowością, ale Bourdieu

$5 \mathrm{Na}$ temat siatki pojęciowej Pierre'a Bourdieu por. Kolarzowski 2014.

$6 \mathrm{Na}$ wielokrotność stosowania metaforyki przestrzennej w naukach społecznych zwracał już uwagę Stanisław Ossowski (1962). Zagadnienie to od strony lingwistyczno-statystycznej poddali badaniom w różnych językach świata przedstawiciele lingwistyki kognitywnej George Lakoff i Mark Johnson (1988). 
posunął go do najdalszych granic spośród wszystkich badaczy. Tak, jak pieniądz dla ojca socjologii Georga Simmela był formą symboliczną związaną z historią ludzkości, dla Pierre'a Bourdieu niemal każda aktywność ludzka, zwłaszcza prowadzona wobec innych, ma znaczenie symboliczne, poprzedzając lub uzupełniając to, co konkretne. Dla sędziego odczytującego wyrok ważne są: miejsce w którym to się odbywa, określony ton głosu, przybrana postawa. Podobnie dla wykładowcy akademickiego miejsce, słuchacze i ich uwaga powinny być tak samo istotne jak konstrukcja przygotowanej wypowiedzi. Jednostka działająca - homo agens - jest w lepszym lub gorszym tego słowa znaczeniu aktorem społecznym i życie wymusza na niej specyfikę związaną przede wszystkim z wykonywanymi obowiązkami w kontekście oraz wobec innych czy nawet samego siebie, ale też często w łączności z potocznymi czynnościami dnia codziennego (np. dobór ubrania w zależności od okoliczności) ${ }^{7}$.

„Przemoc symboliczna” - to najsłynniejsze określenie, a zarazem filar teorii Pierre'a Bourdieu, które pchnęło naprzód antropologię i etnologię kulturową. Mówiąc najprościej, dotyczy ono sfery prywatnej jak i publicznej. Z przemocą symboliczną zaczynamy mieć do czynienia $\mathrm{w}$ momencie rozpoczęcia procesu wychowawczego, a następnie w latach szkolnych. Przemoc symboliczną jesteśmy zmuszeni przyjąć bezdyskusyjnie, aby pozostać w zastanym systemie, nie być karanym, by w końcu nie zostać wykluczonym. Najważniejszym dla przemocy symbolicznej pozostaje wymiar „milczącej zgody” tych wszystkich, których dotyczy. Przemoc symboliczna to jedynie wstęp do „symbolicznej walki”. Warto zauważyć, że to właśnie w walce symbolicznej odzwierciedla się cały potencjał prakseologii Pierre'a Bourdieu, bowiem jego prakseologia to nade wszystko prakseologia walki ${ }^{8}$ :

Przedmiotem nauk społecznych jest rzeczywistość obejmująca wszystkie walki, jednostkowe i zbiorowe, dążące do zachowania bądź przekształcenia rzeczywistości; w centrum uwagi znajdują się te walki, których stawką jest narzucenie prawomocnej definicji rzeczywistości i których czysto symboliczna skuteczność może się przyczynić do zachowania lub też obalenia ustalonego porządku, czyli rzeczywistości (Bourdieu 2008: 193-194).

Ludzka moralność jak i status poszczególnych dyscyplin podporządkowane są walkom prowadzonym w różnorodnych obszarach, na których przyszło nam działać. Symboliczność owych gier, strategii czy walk jest dla niego oczywista. W większości sytuacji społecznych moralność zajmuje uprzywilejowane, ale dopiero drugie, miejsce po zagwarantowaniu sobie priorytetowości swego interesu.

7 Pierre Bourdieu w kilku pracach cytuje badania prowadzone wśród robotników we Francji. Te, które szczególnie przywiązywały znaczenie do wyglądu zewnętrznego i ubrania, nie zawsze w sposób wystarczający dbały o higienę. Zmusiło to na przykład producentów żywności do stosowania otwartych szatni.

8 Polska prakseologia osiągnęła ten poziom już po śmierci Tadeusza Kotarbińskiego w roku 1981, dopiero po opublikowaniu przez Jarosława Rudniańskiego Elementów prakseologicznej teorii walk (1983) oraz Kompromisu $i$ walki (1989). 
Jako socjolog wiem, że moralność działa tylko wtedy, gdy opiera się na strukturach, mechanizmach sprawiających, że ludzie odnoszą korzyść z tego, że są moralni. Żeby zatem mogło pojawić się coś takiego jak niepokój moralny, musi on znaleźć wsparcie i wzmocnienie (nagrody) w strukturze. Źródłem tych nagród mogłaby być również publiczność (gdyby była bardziej oświecona i świadoma manipulacji, którym ulega) (Bourdieu 2009: 88).

Granice pól są przedmiotem ciągłej walki. Historia kształtowania się poszczególnych pól aktywności polegała na osiąganiu coraz większej autonomii, wyzwalania się spod wpływów osób, instytucji, sił zewnętrznych. Istotą jest tu wyobrażeniowe postrzeganie granicy, które niesie w sobie każdy uczestnik danego pola. Znaczenie tych granic urzeczywistnia się na zewnętrz (wobec specyfiki innych pól), jak i do wewnątrz (wobec uczestników danego pola). Otwarcie na zewnętrzne wpływy to przyjęcie obcej logiki, czyli prawomocności innego pola. Przez długie wieki, od czasu plemion po późną gospodarkę stanową, pilnowano homogeniczności pól i ich wzajemnego rozdzielenia , to jest „dystynkcji”. Służyły temu i rytuały, i ogłaszane przez władców prawo.

Skoro walka symboliczna ma tendencje do nieprzekraczania ram wyznaczonych przez bezpośrednie sąsiedztwo i może dokonać tylko cząstkowych rewolucji, oznacza to, o czym była mowa, że jej granicą jest instytucjonalizacja oznak konsekracji oraz poświadczeń charyzmy, takich jak tytuły szlacheckie czy szkolne, zobiektywizowanych znamion szacunku wymagających oznak szacunku, aparatu i ceremonialności, skutkujących nie tylko manifestowaniem pozycji społecznej lecz także zbiorowym uznaniem przypisywanym jej przez sam fakt przyznania uprawnień do dokonywania takiego pokazu własnego znaczenia. [...]. »Grupy statusowe« za pomocą zinstytucjonalizowanych strategii dystynkcji dążą do uznania faktycznych różnic za różnice stałe i niemalże naturalne, a więc prawomocne, symbolicznie podwajając efekt dystynkcji związany z zajmowaniem rzadkich pozycji w strukturze społecznej; zinstytucjonalizowane strategie dystynkcji to samowiedza klasy dominującej (Bourdieu 2008: 189-190).

Współcześnie natomiast mamy do czynienia z homogenizacją pól aktywności człowieka, jak i ze zmaganiem się wpływów jednych obszarów pól na inne, co w szczególnie skrajnych lub niespetryfikowanych sytuacjach (np. młode demokracje) może przybierać formę napierania jednych na drugie, niczym płyty tektoniczne płaszcza ziemi, co wywoływało i może wywoływać opłakane w skutkach trzęsienia ziemi.

Koncepcja Pierre'a Bourdieu wypracowana poprzez wieloletnie badania systemu szkolnego we Francji, sprawdzona na społecznościach osadników północnej Afryki, została przez niego zastosowana do opisu świata mediów. Ten przeciwnik liberalnej nowomowy uznał media, a w szczególności telewizję, za źródło szczególnie niebezpiecznej i niemoralnej opresji społecznej, zagrażającej nawet stosunkowo młodym instytucjom demokratycznym, takim jak niezależne sądy, ekipy rządowe wyłaniane jako konsekwencja wolnej elekcji, czy wszystkich innych instytucji mających swą legitymację w świadomości zbiorowej. 
Chciałbym więc wykazać istnienie ciągu mechanizmów, które czynią z telewizji narzędzie, szczególnie szkodliwej formy przemocy symbolicznej. Przemoc symboliczna jest przemocą, która dokonuje się często przy milczącym współudziale zarówno tych, którzy są jej poddani, jak i tych, którzy ją sprawują. Dzieje się tak poniekąd dlatego, że i jedni, i drudzy nie są świadomi faktu jej wywierania i doświadczania. Zadaniem socjologii, podobnie jak każdej innej nauki, jest odsłanianie tego, co ukryte (Bourdieu 2009: 42).

Niebezpieczeństwo płynące ze strony mediów jest dwojakie: zewnętrzne i wewnętrzne. Podobnie do nauk humanistycznych socjologia może w szczególności służyć do wyjawiania i uwidaczniania tego, co ukryte, nikczemne czy zmanipulowane, ale może też przyczyniać się do ukrywania, a nawet stępiania i obłaskawiania tego wszystkiego, co powinno budzić sprzeciw społeczny. Od czasów Immanuela Kanta, który uważał, że dobrze urządzone społeczeństwo to takie, w którym nawet zły człowiek będzie działał moralnie, minęło tyle samo lat, co od Wielkiej Rewolucji Francuskiej, i jak się okazało - wiele mechanizmów po prostu nie działa. Podobnie eksperyment komunistyczny nie okazał się drogą przyspieszającą rozwój ekonomiczny czy społeczny na oczekiwaną skalę, a ponadto jego bankructwo w ostatniej dekadzie XX wieku pociąga ogromne zagrożenie ze strony korporacjonizmu światowych gigantów, posługujących się mediami w celu wywierania wpływu na społeczeństwa i ich rządy.

Mimo, że istnieje bardzo silna konkurencja między polem dziennikarskim i politycznym, a aktorzy z obu tych pól prowadzą nieustanną walkę (przy czym pole dziennikarskie jest w pewien sposób zawarte w polu politycznym i ma w jego obrębie znaczące wpływy), pola te łączy to, że podlegają bardzo bezpośrednim i niesłychanie krępującym ruchy rządom rynku i plebiscytu. W konsekwencji panowanie pola dziennikarskiego zwiększa skłonność aktorów działających w polu politycznym do poddawania się często gwałtowanym i nieprzemyślanym naciskom, oczekiwaniom i wymaganiom większości, które na skutek formy, jaka nadaje im prasa, przybierają kształt żądań o potencjale mobilizacyjnym (Bourdieu 2009: 114-115).

Jednocześnie ze strony telewizji, która w jego mniemaniu powinna odgrywać rolę podobną do sokratejskiej metody ejałtycznej ${ }^{9}$, mamy do czynienia z różnorodnymi formami nieuczciwości: ze złym traktowaniem ludzi o mniejszych kompetencjach eksperckich, z proszeniem znanych osobistości do wypowiadania się na tematy im obce, do zestawiania osób w panelach, które w życiu codziennym nigdy by się nie spotkały (np. socjologa religii i przywódcę sekty), po to by za sprawą tak stworzonej kakofonii wypowiedzi budować nieprawdziwy obraz dnia codziennego i współczesnej historii. Historia interpretowana z różnych niepowiązanych ze sobą punktów widzenia jest jak niespodziewany cios, jak uderzenie, które ma uczynić ze słuchacza bądź widza jednostkę otumanioną, ,wyrywaną” z tożsamości.

9 Dochodzenie do prawdy poprzez zadawanie coraz większej ilości pytań rozbijających utarte klisze językowe. Przez P. Bourdieu użyte w sensie mocno ironicznym wobec „klangoru” dziennikarzy telewizyjnych. 
Wszytko, co związane jest z mediami, szczególnie zaś telewizją, poddane jest plebiscytowi rankingów, wypaczając i wulgaryzując wszelkie standardy:

Wszystko to sprawia, ze wciąż rosnąca dominacja pola dziennikarskiego (które samo poddane jest rosnącemu panowaniu logiki komercyjnej) nad polem politycznym - zawsze nękanym pokusą demagogii (szczególnie w sytuacji, gdy sondaż dostarcza narzędzia uprawiania jej w sposób zracjonalizowany) - przyczynia się do osłabienia autonomii pola politycznego i zarazem do osłabienia przyznanego reprezentantom (politycznym lub innym) prawa do powoływania się na swoje kompetencje eksperckie i na swój autorytet strażników wartości zbiorowych (Bourdieu 2009: 116).

Niszczenie zaufania do specjalistów ze szklanego ekranu to zdaniem Bourdieu pierwszy krok do łamania wszelkich zakazów i posługiwania się metodami kryminalnymi do momentu, w którym nie zostanie to wykryte. Stąd atak szacownego socjologa na media lat dziewięćdziesiątych XX stulecia, który porównywał je do sportowców stosujących niedozwolone metody dopingu:

Tym sposobem natężenie pola dziennikarskiego, które samo jest coraz bardziej poddane bezpośredniej lub pośredniej dominacji logiki komercyjnej, zagraża autonomii pozostałych pól produkcji kulturowych. Wzmacnia ono w każdym z nich tych aktorów (lub te instytucje), którzy są bardziej podatni na pokusę „zewnętrznych” zysków. Dzieje się tak, ponieważ mają oni mniej specyficznego dla danego pola kapitału (naukowego, literackiego, itd.) i mniejsze szanse na specyficzne zyski, które to pole zapewnia w bliższej lub dalszej przyszłości (Bourdieu 2009: 111).Istotnym problemem socjoanalizy stał się dla Pierre'a Bourdieu mechanizm tworzenia ról społecznych, ról którymi poszczególni homo agens będą posługiwać się na co dzień i w życiu rodzinnym oraz zawodowym (Bourdieu 2004). Pierwszym kryterium prawidłowego określenia ról jest logika. Ale nawet ta pragmatyczna nie może stanowić wyłącznego kryterium weryfikacji dla całej złożonej strony ludzkiego behavior - zachowań. Zachowania jednostek poddane są presji grupowej. Te dyktowane przez grupę przybierają często postać sinusoidalną. Ich logiczność lub jej brak uzależniona jest od określenia za pomocą porządkującego kwantyfikatora - czasu i sposobów jego odczuwania czy postrzegania.

W przeciwieństwie do logiki, pracy myśli polegającej na myśleniu o pracy myśli, praktyka wyklucza jakiekolwiek zainteresowanie stroną formalną. Jeśli nawet zdarza się refleksyjny powrót do samego działania (a więc zawsze, gdy automatyzmy zawiodą), będzie on podporządkowany dążeniu do osiągnięcia celu i staraniu (które nie koniecznie tak będzie postrzegane) do maksymalizacji zysków z włożonego wysiłku. Nie ma on też nic wspólnego z chęcią wyjaśnienia, jak osiągnięto dany rezultat a jeszcze mniej z próbą zrozumienia (Bourdieu 2008: 123).

Pierwszeństwo interesu jest dla Pierre'a Bourdieu bezsporne. Granicą dla chęci posiadania jest najczęściej drugi człowiek i dopiero pod koniec XX wieku okazało się, że problematyka 
ekologiczna wkroczyła do wielu dziedzin, zagospodarowując związki między naukami poprzez wskazywanie zagrożenia istnienia gatunku ludzkiego na Ziemi. Uczymy się przez całe życie od związków przyczynowo-skutkowych aż po relacje miłosne i kondycje przywódcze, zakładające ogromne możliwości przewidywania zachowań innych. Myślenie życzeniowe człowieka homo agens idzie w kierunku od pogodzenia dążeń do posiadania z etyką. Jednakże taka sytuacja może zdarzyć się przy określonej konkurencji, przy utartych regułach postępowania i w sytuacjach możliwych do przewidzenia. Intensywna dynamika zmian czyni z socjoanalizy naukę niezbędną. Zanim rozpoznamy zagrożenia niszczące nasze tożsamości, interesy i struktury polityczne czy społeczne musimy wiedzieć i o nich, i o nas w odniesieniu do nich - wystarczająco dużo. Niestety zdaniem Pierre'a Bourdieu nadchodzi epoka powszechnej bezwiedności ${ }^{10}$ w nadmiarze posiadanych narzędzi i zgromadzonej wiedzy.

\section{BIBLIOGRAFIA}

Bourdieu, Pierre. 1982. Ce que parler veut dire: L'économie des échanges linguistiques. Paryż: Fayard.

Bourdieu, Pierre i Terry Eagleton. 2009. Doksa i życie codzienne. O habitusie, oświeconej fatszywej świadomości i rapie rozmawiają krytyk ideologii i realista. „Recykling Idei” 12, http://recyklingidei.pl/bourdieu-eagleton-doksa-zycie-codzienne [Dostęp 10.03.2019].

Bourdieu, Pierre. 2005. Dystynkcja. Społeczna krytyka władzy sądzenia. Tłum. P. Biłos. Warszawa: Wydawnictwo Naukowe Scholar.

Bourdieu, Pierre. 2004. Męska dominacja. Tłum. L. Kopciewicz. Warszawa: Oficyna Naukowa.

Bourdieu, Pierre. 2008. Zmyst praktyczny. Tłum. M. Falski. Kraków: Wydawnictwo Uniwersytetu Jagiellońskiego.

Bourdieu, Pierre. 2009. O telewizji. Panowanie dziennikarstwa. Tłum. K. SztandarSztanderska i A. Ziółkowska. Warszawa: PWN.

Bourdieu, Pierre i Loïc J. D. Wacquant. 2001. Zaproszenie do socjologii refleksyjnej. Warszawa: Oficyna Naukowa.

Kolarzowski, Jerzy. 2006. Supremacja prawdy: filozofia Tadeusza Kotarbińskiego w poszukiwaniu wspólnego fundamentu dla reizmu i etyki niezależnej. W: Myśl Tadeusz Kotarbińskiego i jej współczesna recepcja. Warszawa: Polska Akademia Nauk, Towarzystwo

10 Bezwiedność w rozumieniu Pierre’a Bourdieu oznacza całe spectrum znaczeń, które temu terminowi nadał Arystoteles - stan, który sam przez się stanowi o winie, ponieważ wysiłek w celu zdobycia wiedzy i umiejętności przewidywania były wysoce niewystarczające. Jednocześnie stan bezwiedności może tłumaczyć nieprawidłową aktywność ludzką - bezwarunkowość, bezwolność, instynktowność, mimowolność, nieświadomość, odruchowość. 
Naukowe Prakseologii, s. 27-34.

Kolarzowski, Jerzy. 2014. Wprowadzenie do teorii socjologiczno-prakseologicznej Pierre ‘a

Bourdieu. W: D. Strus i A. Duk-Majewska (red.). Administracja, samorzad, prawo.

Ksiega jubileuszowa z okazji dziesięciolecia funkcjonowania Instytutu Administracji,

Samorzadu i Prawa UPH w Siedlcach. Warszawa: Wydawnictwo Aspra, s. 81-92.

Kotarbiński, Tadeusz. 1974. Abecadło praktyczności. Warszawa: Wiedza Powszechna.

Kotarbiński, Tadeusz. 1986. Prakseologia a ekonomia. W: Drogi dociekań własnych. Fragmenty filozoficzne. W setna rocznice urodzin. Warszawa: PWN.

Lakoff, George i Mark Johnson. 1988. Metafory w naszym życiu. Tłum. T. P. Krzeszowski. Warszawa: PIW.

Marcuse, Herbert. 1991. Człowiek jednowymiarowy. Badania nad ideologia rozwiniętego społeczeństwa przemysłowego. Tłum. W. Gromczyński. Warszawa: PWN.

Ossowski, Stanisław. 1962. O osobliwościach nauk społecznych. Warszawa: PWN.

Rudniański, Jarosław. 1983. Elementy prakseologicznej teorii walki: z zagadnień kooperacji negatywnej. Warszawa: PWN.

Rudniański, Jarosław. 1989. Kompromis $i$ walka: sprawność $i$ etyka kooperacji pozytywnej $i$ negatywnej w gęstym otoczeniu społecznym. Warszawa: Instytut Wydawniczy PAX.

Sołżenicyn, Aleksander. 2014. Dwieście lat razem. Tom II. W porewolucyjnej Rosji. Tłum. A. Mayer i N. Krzyżanowska-Barwińska. Wrocław: Wydawnictwo Wektory.

Znaniecki, Florian. 2013. Upadek cywilizacji zachodniej. Warszawa: Wydawnictwo Uniwersytetu Warszawskiego.

Zubow, Walentin. 2015. Lata przez męke Rosja 1917-1925. Przeł. D. Ulicka. Warszawa: Wydawnictwo Akademickie Sedno.

\section{Crossroads of praxeology in the second half of the 20th century:}

\section{Tadeusz Kotarbiński and Pierre Bourdieu}

ABSTRACT: Pierre Bourdieu and Tadeusz Kotarbiński were materialists. Nevertheless, the French social researcher and subsequently the thinker was a permanently epistemological materialist (he questioned and many times reconstructed his own projects). He researched human behavior in a manner that was surely certain, stripped of even minimal trust in the durability of the findings, questioning how much it could make sense - the significance of the results obtained. Tadeusz Kotarbiński, on the other hand, turned to historical-dialectical materialism as a 
theory of social being supported by the attitude of a scientific atheist, seeking supremacy of the truth and a world of permanent certainty. Thanks to this combination we can show the methodological dilemmas of praxeology. For Kotarbiński praxiology is a spontaneous normative science. For Bourdieu praxeology reveals itself from the pressure of axiology - the instinct of possession and becomes part of the sociological analysis of activities (including communication activities).

KEYWORDS: praxeology, sociological analysis of human action, Kotarbiński, Bourdieu 